\title{
La adaptación cinematográfica como un tipo de traducción literaria interespecies en la enseñanza de los futuros filólogos
}

\author{
Film adaptation as a type of interspecies literary translation in \\ teaching students majoring in philology
}

\author{
Maryna V. Olkhovyk ${ }^{1 a}$, Larysa V. Gorodnycha ${ }^{2}$, Svitlana M. Gergul ${ }^{3}$, \\ Olena V. Sazonova ${ }^{4}$, Inna V. Kyian ${ }^{5}$ \\ T.H. Shevchenko National University "Chernihiv Colehium, Ukraine. ${ }^{12345}$

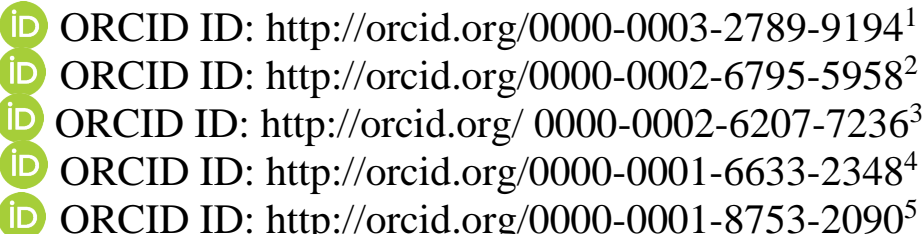

Recibido: 27 de junio de 2021

Aceptado: 02 de noviembre de 2021

\section{Resumen}

El presente estudio tiene como objetivo investigar el proceso de transformación del texto en el curso de la traducción literaria interespecies en la enseñanza de posibles filólogos basados en la aplicación de interpretaciones de obras literarias. Se ha utilizado el complejo de métodos para implementar las metas y objetivos del estudio: consolidación y sistematización del conocimiento, método hermenéutico, método comparativo, el análisis etimológico, el método bibliográfico y descriptivo, método de especies de género y método estructural-funcional. Los autores identificaron los tipos de adecuación de la traducción literaria entre especies y mostraron su implementación práctica durante el proceso de enseñanza donde la adaptación cinematográfica se definió como una técnica universal. Los resultados de la investigación permiten describir el proceso de transformación del texto de una imagen primaria a una nueva. En conclusión, los autores afirman que la interpretación es un concepto fundamental para la traducción literaria interespecies basada en la exposición del texto y la transformación de la fuente. Este proceso está vívidamente ilustrado por una adaptación cinematográfica que simplifica los mecanismos de las traducciones intertextuales durante la formación de competencias profesionales de los posibles filólogos. Esto, a su vez, permitirá desarrollar la metodología de la adaptación cinematográfica mientras se enseña a los futuros filólogos.

Palabras clave: texto, literatura, traducción literaria interespecies (ILT), filología, cinematografía, hermenéutica.

\footnotetext{
${ }^{\text {a }}$ Correspondencia al autor:

E-mail: marynaolk3@gmail.com
} 


\begin{abstract}
The aim of the research is to study the process of text transformation in the course of interspecific literary translation in teaching students majoring in Philology students majoring in Philology based on the interpretations of literary works. To fulfill the research objectives a set of methods were involved: consolidation and systematization of knowledge; hermeneutic method; comparative method; the etymological analysis; the bibliographic and descriptive method; genre variety method; structural-functional method. The authors identified the types of adequacies of interspecies literary translation and showed their practical implementation in teaching, where film adaptation was defined as a universal technique. The research results allow us to describe the process of text transformation from an initial state to a new one. In conclusions, the authors state that interpretation is a fundamental concept for interspecies literary translation based on a text interpretation and transformation of the source. This process is vividly illustrated by a film adaptation that simplifies intertextual translation mechanisms in the course of developing professional competence in students majoring in Philology. This, in turn, will let develop the methodology of film adaptation in teaching students majoring in Philology.
\end{abstract}

Keywords: text, literature, interspecies literary translation (ILT), philology, film adaptation, cinematography, hermeneutics.

\title{
Introduction
}

Translation in its various manifestations, such as literary, natural, technical, and others, remains one of the universal methods in the course of developing professional competence in students majoring in Philology. For the other hand, the notion of translatability has long been the subject of discussion. There are various views and opinions on the definition of the translation as a general aesthetic phenomenon, particularly in its relationship with the concept of literary interpretation. Although these phenomena coincide at specific points, they are independent but still need terminological separation and recognition of originality and autonomy to each other, and hence the methodological correlation. All this led us to the definition of a modern literary discourse category as " interspecies literary translation". To better understand the term and its methodological usage, it is worth considering the basic concepts that form the ILT phenomenon and can be used in teaching students majoring in Philology.

The comparative method, together with the bibliographic descriptive one, allowed identifying the position of scholars (Arutyunyan, 2007; Barthes, 1994; Deleuze, 2004; Foucault, 1996; Ivanova, 2011; Lotman, 1973, 1992; Sontag, 1964; Reisenauer 2015; Zubryts'ka, 2007), which is close to the author's position concerning the relation between the primary text and its interpretations. This method contributed to the determination of the differences and common 
features between the original text and the text which is a product of ILT, presented mainly in the research schemes.

The structural-functional method was used to identify the impact of ILT on contemporary humanities discourse, in particular on translation theory, and to outline the prospects of using the phenomenon of the film adaptation in the context of teaching methods for students majoring in Philology (e. g. how film transcription can be applied to create methods of studying literary translation).

Therefore, the aim of the research is to investigate the process of text transformation in interspecies literary translation on the example of literary film adaptations to implement it in teaching students majoring in Philology. The aim determines the main research objectives:

1) describe the problem of the thesaurus of interspecies literary translation;

2) examine structural components of original texts for interspecies literary translation;

3) identify the types of ILT adequacy and show their practical implementation in teaching;

4) identify peculiarities of cinematic transcription of literary works as a specific type of artistic interaction that should be considered in teaching;

5) define film adaptation as a universal technique in the training of students majoring in Philology.

\section{Literature review}

To better understand the nature of ILT, it was necessary to consider the theoretical foundations of the concept of text and their transformation in postmodern discourse. Accordingly, we focused on the works of Bakhtin (1975), Lotman (1973), and Barthes (1994), because they extended the boundaries of understanding the text to the "cultural fabric", eliminating the author and bringing a multitude of interpretations to the fore.

The studies by these authors on time and space in the context of screen and fiction text interpretation are of particular note. The paper analyzes the temporal and spatial characteristics of cinematic transcription as understood by Lotman (1973) and his "freedom of the artist", Bakhtin's (1975) theory of temporal-spatial models (McCaw, 2015), and the importance of image-time in Deleuze's (2004) concept. A contemporary reading of these scholars, notably Hwan (2015) and Monticelli (2019), adds key emphases to understanding Lotman's (1973) legacy.

By his part, Umberto Eco's (2013) theory on the limits of the open text has provided an in-depth look at the cinematic text and its poetics in the light of the plurality of 
interpretations. His work covers the issue of the text as open to all variations and readings in the postmodern discourse, taking into account the importance of the author's position against the broad cultural background.

The research of the renowned British cultural historian Hobsbawm and Ranger (2010), The Invention of Tradition, which is considered one of the most influential books on the history of ideas, as well as studies of his creative legacy, is essential from the point of view of theorizing screen processes in the context of global cultural phenomena (Mazower, 2012). The issues of ILT of the literary text are based, first of all, on the tradition of comparative analysis of the verbal and visual, which has become particularly conspicuous in various research works starting from the $20^{\text {th }}$ century to the work of Eco (2013), Lotman (1973), Dudley (1984), Helman (1998).

The definition of interspecies literary translation of a literary text is intertwined with the research into the interpretation. Linguists, philosophers and art historians have been working on this notion for many centuries. Deleuze's (2004) and Barthes' (1994) ideas, which we mention in our research, are of great value for the terminological expansion of the concept "interpretation". The interconnection of cultural languages and cultural universalities was actively considered in structuralism and postmodernism, especially by mentioned authors.

The theoretical foundations of film adaptations of literary works have been studied in academic, art, and cultural outcomes of modern scientific discourse, mainly focusing on translating literary works into cinematic language. The translation of literary works into the language of cinema has been most widely considered in theoretical and practical research. Perdikaki $(2017 ; 2018)$ studies film adaptation as a modality of translation and provides a systemic analysis of the changes occurring in the adaptation of a novel for the big screen. Also, Viana da Silva (2013), while researching modern narratives and film adaptation as translation, analyzes the translation of representative contemporary narratives into films and discusses ways of reading these literary texts in the new media and possible implications to their reception.

Regarding the methodological aspects of the use of literary translation in teaching, we should mention that the effects of the marking method on the assessment of literary translations in a pedagogical context were examined (Wang \& Wang, 2020). Attention was also paid to the differentiation of such concepts as "film translation" and "audiovisual translation" (Zhuravel, 2018). Valdeon (2018) investigates texts which study a variety of languages (including English, Spanish, Italian, Chinese, French, Japanese, Dutch, German and Swedish), use a wide range of approaches (quantitative review of literary translations; transfictional approaches to translation; a review of concepts such as paratexts, intralingual translation, intertextuality and retranslation; 
and so on), and aim to expand the existing debates on translation and translation studies as a subject. At the same time researches discuss how the nature of literary translation differs from other forms of translation by looking at practical difficulties and challenges notable in a specific language (e. g. the Arabic language and translation) (Khrais, 2017). But no one has compared it in the Ukrainian language.

For the other hand, Koletnik (2020), exploring the potential and limitations of employing translation in the additional language teaching of students majoring in Translation, paid attention to strengthening selected aspects of students' grammatical competence, followed by an investigation of its subsequent effect on the development of their translation competence. Finally, the peculiarities of using media texts in developing the professional competence in students majoring in Philology and editors have been studied, and some exercises have been suggested (Gorodnycha \& Olkhovyk, 2018). Given all these antecedents, it can be said thar the study of ILT enhances the methodological possibilities of students majoring in Philology ' professional and translation competence formation while studying foreign languages, editing or culture.

\section{Results}

The translation is the primary technique in the training of philologists and other literary competence and the Ukrainian language, because translation varieties allow developing skills of high fluency in foreign languages and the Ukrainian language. In this case, we focus on this type of translation, which methodologically enables the teacher to cover the entire possible spectrum of actualization of skills without intermediate language competence, and indirectly the skills of critical thinking, aesthetic taste, and artistic reflection, interpretation of texts and reading famous texts interpretations by other authors. The text means here postmodern reading (Barthes' reading), where the entire culture is understood as a text. So, any cultural image (story, book, painting, film, cinema, music, and others) can be a relevant example of a philologist's work with translation.

Another point to discuss is what a literary text gives students majoring in Philology in terms of the teaching methodology. Above all, this can be the diversity of knowledge, which will be acquired and actualized in the course of translation of different types of texts. It can also be a simple interpretation or a continuation of the fiction text, or a translation into a slang of a particular social group, understanding of the author's idea or a suggestion for a different reading of the context, and others. Secondly, such work with a literary text provides an update of other vectors of information: from the author's own writing experience to the hermeneutic 
body (epoch) that triggered the emergence of the text. Thirdly, it is the variability of translations of literary works: from translation into another language to the study of the term, the interpretation as another type of translation of a particular academic assignment. Finally, all this provides a wide methodological opportunity, which may be studied, and a theoretical possibility for understanding the accents to be taken into account in the learning process (see Figure 1).

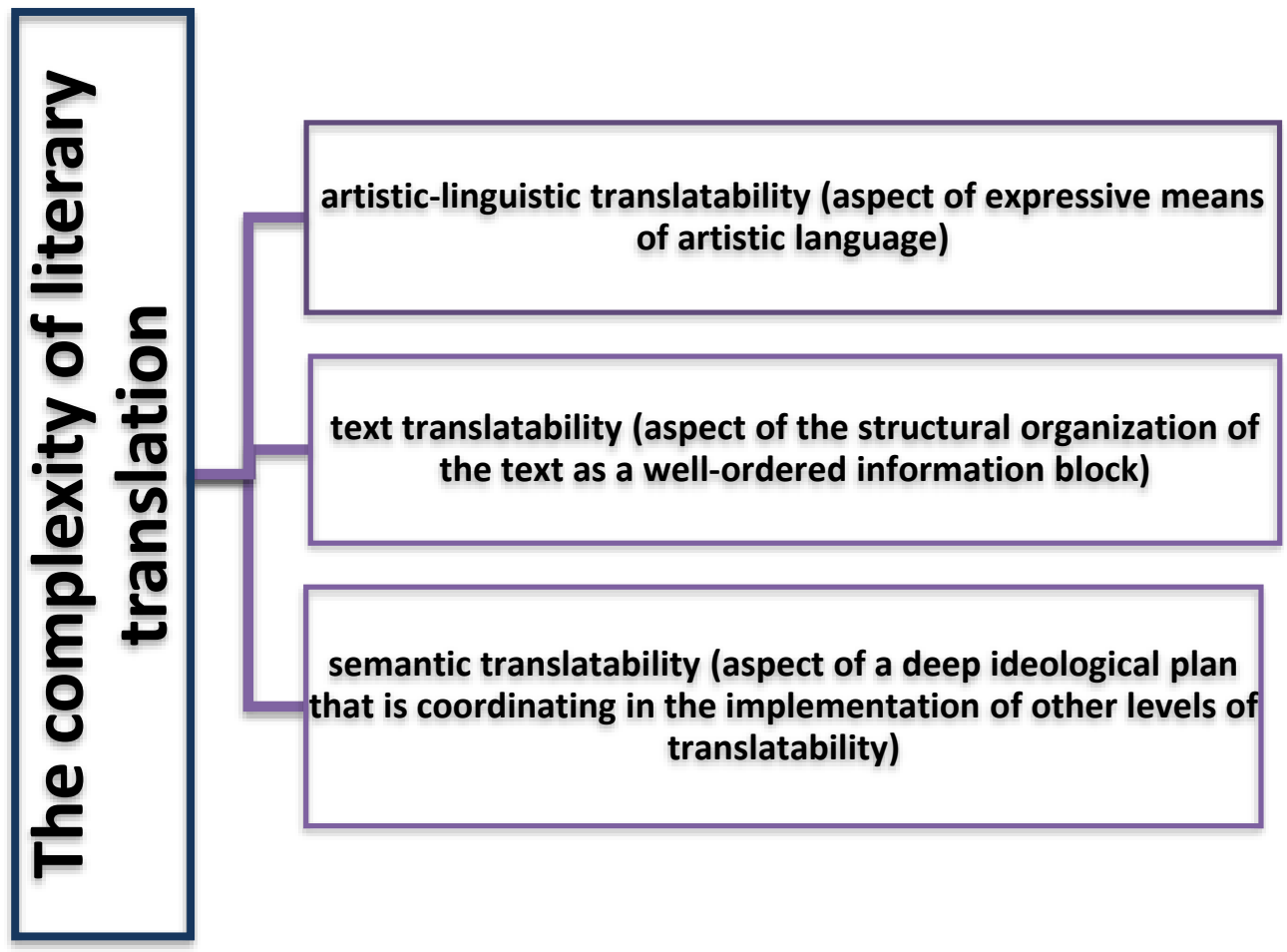

Figure 1. The complexity of literary translation

Literary translation is one of the types that became the basis for developing the concept of ILT. The literary translation is always an interpretation in which it cannot be simply copying of the text. However, it is always realized as an understanding of the latter, and it always involves interpreting the text in a new, figurative-conceptual system that should be used in the development of professional competence in students majoring in Philology. Also, film adaptation involves working with a literary text, which allows this technique to be used methodologically in a comprehensive manner both in terms of language and empirical material. This allows identifying this technique as a universal one in the training of philologists.

The complexity is the subjectivity of the recipient-interpreter's creative vision, which inevitably affects the spiritual atmosphere of modern times, combined with purely objective 
requirements for the adaptation of literary material to the specifics of cinematic language. Therefore, defining film adaptation as a technique in teaching students majoring in Philology, we primarily pay attention to the use of cinematic language. This provides the use of pictorial and expressive means (construction of the frame and its subject content, editing, acting, music, and others); therefore, we should focus on the fact that cinematic language is significantly different from the artistic means of the art of speech. The elements of cinematic language also include such means of expression as perspective, lighting, color, sound effects. However, an essential feature of cinematic language is that each element acquires meaning only in the context.

The impossibility of identical conveying the artistic content of a literary source with the help of the language of another kind of art causes its semantic overemphasis, the introduction of new artistic meanings into its screen version. This fact must be considered in developing the methodology of teaching students majoring in Philology the introduction of the study of film adaptation as a variant of translation of a literary text (see Figure 2). 


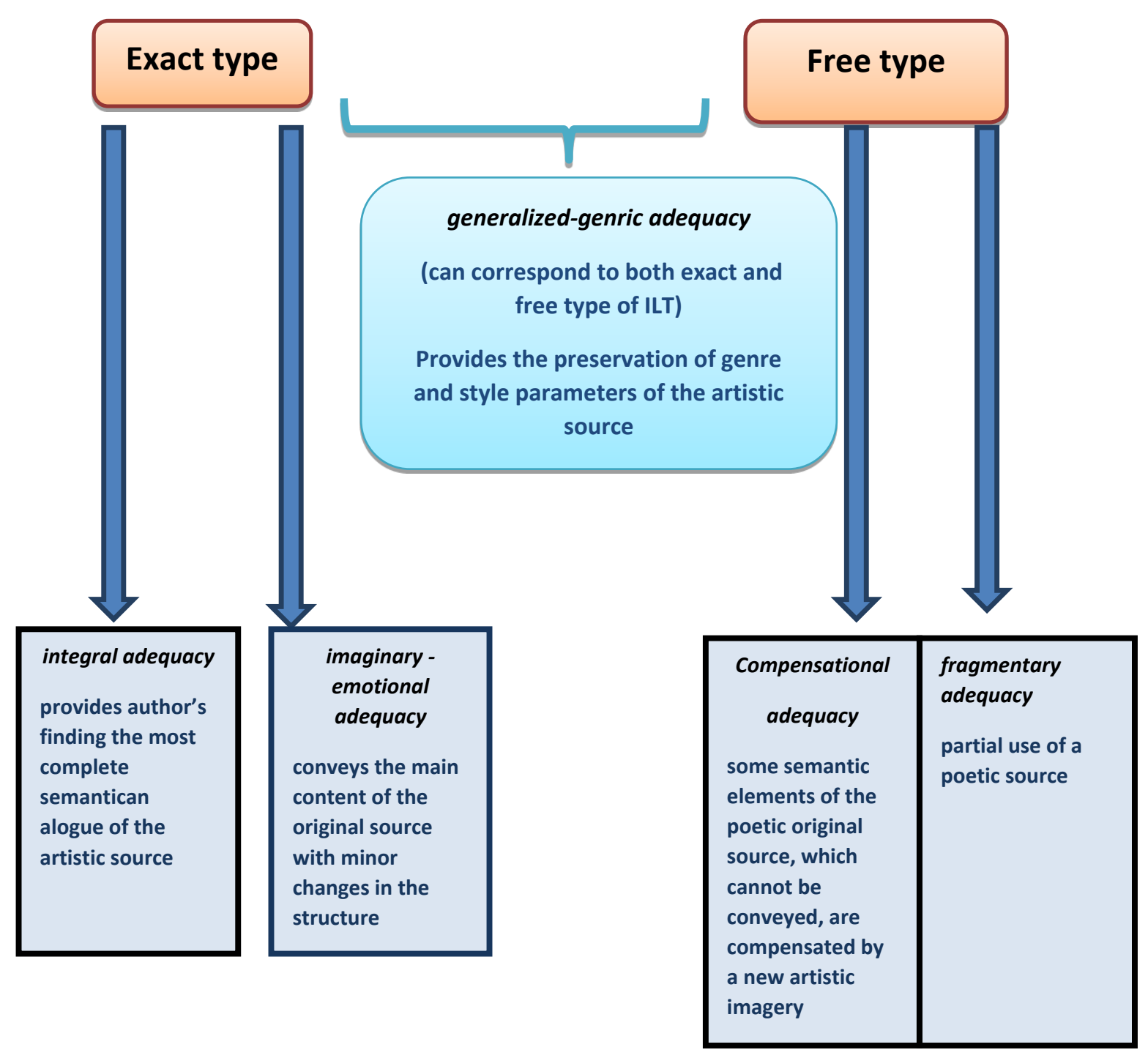

Figure 2. Differentiation of interspecies literary translation (ILT) types depending on the adequacy of the work

The screenplay is the primary basis for creating the film, which acts as a cinematic text. It should be emphasized that the nature of the screenplay is dualistic, with the word serving the visual image. The film script is mainly interpreted as an independent work of art, although it does not represent a new kind of art, only a new literary form. A screenwriter who ventures into the verbal visualization of a primary literary source should have a good command of both semiotic languages and be aware of the subordination of the laws of cinema.

The brightest world films of recent years, which did not become a banal illustration of stories, but opened new intonations and unexpected contexts in them: The Girl with the Dragon Tattoo (2009), directed by Niels Arden Oplev, based on the novel of the same name by Stig Larsson; Faust (2011) directed by Alexander Sokurov, based on the work of the same name by Johann Wolfgang von Goethe; We Need to Talk About Kevin (2011), directed by Lynne 
Ramsey, based on Lionel Shriver's novel The Price of Love; House with a Turret (2012) directed by Eva Neumann, based on the story of the same name by Friedrich Gorenstein; On the Road (2012) directed by Walter Salles, based on the novel of the same name by Jack Kerouac; Fantastic Beasts and Where to Find Them (2016) directed by David Yates, based on J. K. Rowling's novel of the same name; Inferno (2016) directed by Ron Howard, written by Dan Brown; The Call of the Wild (2020) directed by Chris Sanders, based on Jack London's novel of the same name, and others. They offer their original approach to the translation of prose in a specific, different, cinematic language.

We can outline quite a successful screen embodiment of Ukrainian classics such as I. Franko's play Stolen Happiness (films by Shmaruk \& Yura, 1952), I. Kotlyarevskyi's play Natalka-Poltavka (director: RodionYefimenko, 1978), I. Nechui-Levytskyi's novel The Kaidash Family (director: Volodymyr Horodko (1996), Panteleimon Kulish's novel Black Council (director: Zaseieev-Rudenko, 2002), etc. In the opinion of the experts, the best film adaptation in Ukrainian cinema is M. Kotsyubynskyi's novel Shadows of Forgotten Ancestors, which was directed by Serhii Paradzhanov; Vii (2014), written by Mykola Hohol, directed by Oleh Stepchenko; Black Raven (2019), based on Vasyl Shkliar's novel of the same name; Devoted (2020), based on Sofiia Andrukhovych's novel Feliks-Avstriia; finally, Zakhar Berkut (2020), based on Ivan Franko's novel of the same name.

In this light, a genre of the cinematic story is of great interest. It joins the artistic elements, which created a specific type that embodied both a screenplay feature and a short novel. Examining particular features of both kinds of art (movie and literature) is elaborated into a cinematic story to understand the investigated phenomena better. The general concept of the story is top priority. It is worth mentioning that some problems are found in the interpretation of the genre of a cinematic story because one can find different views on this concept. Let us consider some of them:

1) based on understanding, there is a volume of this work; a cinematic story should be a full-length feature one-part film (if it is a two-part film, it is rather a film novel and short film).

2) there is eventfulness, the cast of the characters: the character in the film solves a problem (not the most global, often lyrical or production problem); while the film does not claim to high spirits, telling "about human lives", the cinematic story is "human" at first glance and has a weakened dramatic structure.

3) there is an adaptation to the script; a cinematic story is often an adaptation of the novel, but it can also be several stories or a short novel at its core. But a simple formation from 
the theoretical point of view has a problem in it, and the problem lies in the fact that it is at the border of two terminological paradigms (literary and cinematographic).

Therefore, a cinematic story is not always a film but rather a published screenplay or generally a literary text that potentially contains a film and could be adapted into a movie. This is why the cinematic story may remain only a printed story, but it can become an excellent empirical material for students majoring in Philology to study certain aspects of literary translation. For the other hand, the features of the film script are fragmentation, montage composition, expansion of dialogues, plot dynamics. Since the parts of the novel are epic principles of the life depiction, metaphor, author's digressions, vivid landscape pictures, you may assume at first glance that one cannot combine the incompatible, for instance, fragmentation and epics. This is, however, the specifics of the cinematic story (see Figure 3 ).

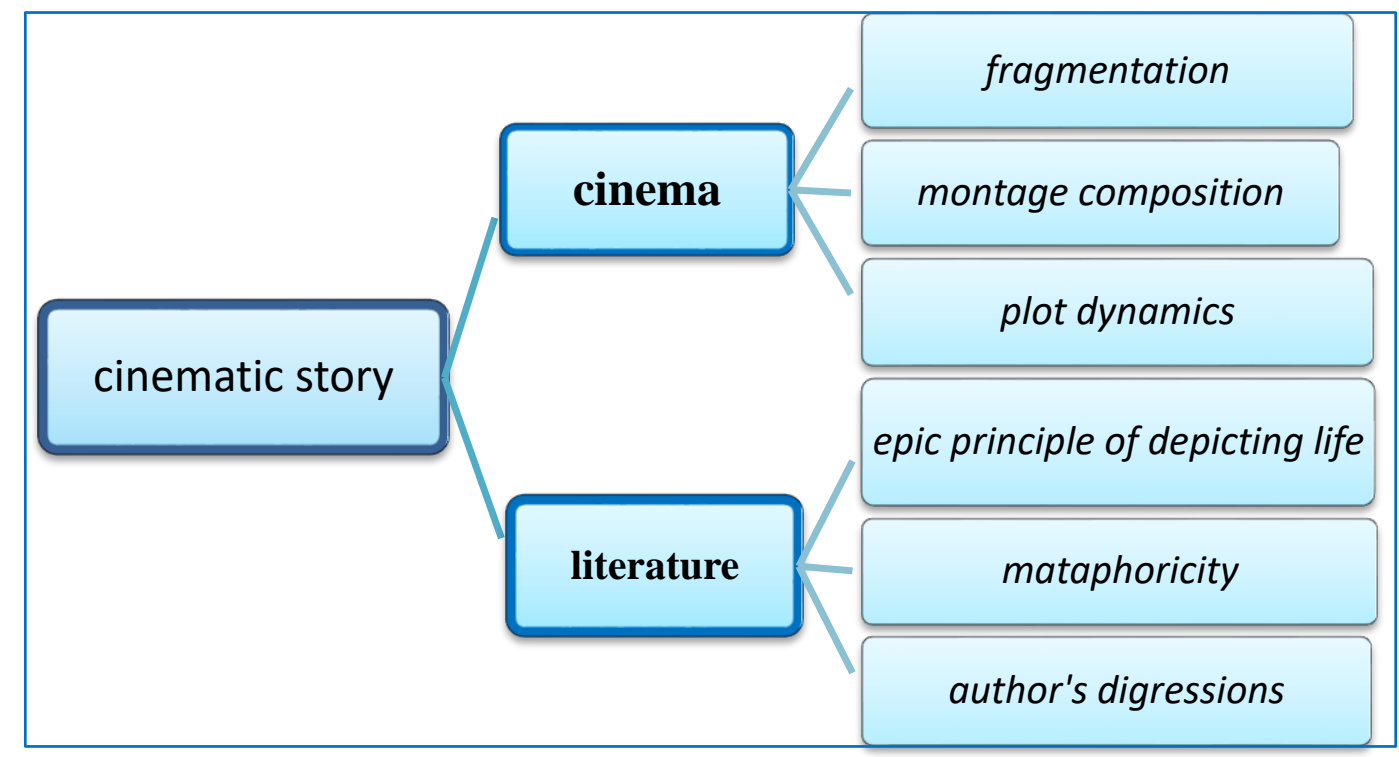

Figure 3. Features of cinematic story

In comprehending significant layers of reality, the authors use montage composition, which resembles individual shots linked together into an artistic coherence, the writer's creative intent and the development of the artistic idea. The cinematic story is close to drama with its dynamic and substantive dialogues.

\section{Discussions}

The phenomenon of the film adaptation in the context of the methodology of translation implies cinematic language as an object of theoretical reflection. Exploring the specifics of the literary language of cinema, cultural scientist and semiotician Lotman (1973) 
describes its essence as "a synthesis of two narrative tendencies-pictorial ("moving painting") and verbal", which is characteristic of ILT. That is why new semantic nuances are revealed at two levels of film narrative in a film adaptation. First, it can be done at the level of verbal narrative through the selection and transformation of fragments of the original text to be voiced by characters, through the distribution of narrative between actors, and sometimes "behind-thescenes" voice (titles can perform their function). Second, it is revealed at the level of the actual cinematic language through visualization and nonverbal elements of "sounding" (specifics of intonation of utterances, noise effects, music) verbal images of literary work.

Comparative analysis of literary work and its film adaptation can be defined as interdisciplinary research, which allows updating knowledge of different branches of the general and vocational field of students majoring in Philology. The term "cinematic transcription", which appeared at the turn of the $20^{\text {th }}$ century, must be considered. However, the correlations between film adaptation and cinematic transcription have many identical characteristics, so that we will use them as synonymous in the future.

Cinematic transcription in a broad sense is a product of the interaction of literature and cinematography. Sontag in her works interpreted cinematic transcription as the transfer of a literary work into the sign systems of other arts (songs, illustrations, performances, films) (Moser, 2019). Hence, we can interpret it as peculiar relevance of the free and precise type of appropriateness in the process of ILT. We suggest "fidelity to the original" as one of the first criteria for assessing cinematic transcription. Within this concept, "fidelity to the letter" and "fidelity to the spirit" of the original are distinguished. It is a question of the limits of interpretation of a work that directly concerns the methodological foundations of literary translation. On the one hand, Helman (1998) notes the variant where a director makes a literal reading of work and recreates it on the screen, and on the other hand, a director makes an almost new text on the screen recreating only the idea of the work. The researcher notes the limitation of the creative process in the situation of the first approach because the space of the text itself should be recreated on the screen.

While the film version of a work can be recognized and justified, the search for the spirit of the original in the film is profoundly subjective. This provides a wide range of methodological possibilities for involving film transcription as a technique in the teaching process. From that point of view, cinematic transcription is an interesting cultural phenomenon, where certain varieties have to be considered, particularly in a rather popular classification by Dudley (1984). These are borrowing, transforming and intersecting. Borrowing seems to be the best model for building a methodological technique for introducing film adaptation into the 
educational process of students majoring in Philology. The director uses ideas, themes, individual scenes, and the form of a longer text while implementing it. Such a film demonstrates the source of the strength of the original, analyzing it and reaching out to the enduring forms and archetypes of culture.

In Lotman's (1973) opinion, spatiotemporal characteristics of the object are of great value. Researcher of literature and cinema Lotman (1973: 99-100) wrote: "Cinematography models the world. The essential characteristics of the world are space and time. The relationship of the spatiotemporal characteristics of the object to the spatiotemporal nature of the model largely determines its essence and cognitive value. The cognitive value of the model increases depending on the artist's freedom to choose modelling tools". Significant changes in the literary background accompany such transformations of the text into cinematic text. That is why we should primarily mention chronotope. Defining the role of chronotopes in literature, Bakhtin (1975) emphasized that "they are the center of the novel's main plot events. In the chronotope, the plot knots are tied and untied. We can directly say that they have the main plot-forming value" (p. 281). On-screen chronotope is the compositionally shaped space in time in which the characters act. The author's perception of value-meaningful parameters of the world is indirectly reflected in the specific arrangement of the film's time-space in the composition of the frame, its geometry, and the structure of the time coordinate. Creating artistic reality, artists have to deal not with those speculative parameters but with the phenomena and objects of the natural world. Overall, the visual or audiovisual expression recorded on film offers roughly two types of links with the world: with the real thing and with the author's perception of it, both at the level of logical construction and the level of the intuitive perception of the image.

It's worth to mentioning thar space (as representation) and time (as duration) are integral components of any cinematic work, and they are equal in this sense. However, moving from a purely "subjective" level to a more creative dimension makes clear that there are films primarily focused on objectivity and spaciousness, and those that appeal mostly to temporal categories. For example, analyzing the cinematography of the war period, Deleuze admits the superiority of time image over movement image, which is closely linked to the phenomena of the character's inner life. Furthermore, Deleuze (2004) does not regard movement or displacement, nor change of position in time and space, but considers the time.

In general, the category of the genre is historically changeable and can be brought in line with the general needs of modern life. The classification of film genres is not entirely complete, as a single film can have the attributes of different genres, which should be considered in the development of ILT guidelines. 


\section{Conclusions}

A film adaptation is a type of ILT that has an everyday basis for its interpretation. "Most preferable" film adaptation is a creative analogy of the adapted work and its interpretation into cinematic language, preserving the main features of the content and style of the source. Also, film adaptation involves two levels of cinematography. On the one hand, there is verbal storytelling (selecting a fragment of the primary source) and the text distribution between the actors. On the other hand, there is a manifestation at the level of cinematic language visualization (a non-verbal voiceover of the verbal images of a literary work).

For the other hand, comparative analysis of a literary work and its adaptation are new meanings of interstitial recoding, which provides a wide range of methodological opportunities for using in the study of students majoring in Philology. All this allows developing the exercises to improve the professional and translation competences of students majoring in Philology. The analysis and recreation of the cinematic story or cinematic novel of famous literary works, work with foreign and Ukrainian original texts are the problems we should study in our further works.

\section{References}

Arutyunyan, S. M. (2007). Semiotic boundaries in art (cultural analysis). Moscow: MGUKI.

Bakhtin, M. (1975). Forms of time and chronotope in the novel. Essays on Historical Poetics. In M. Bakhtin (Ed.), Literature and aesthetics (pp. 234-407). Moscow: Imaginative literature.

Barthes, R. (1994). Selected works: Semiotics. Poetics. Moscow: Progress.

Bobrova, N. E., Lebedev, A. V. \& Pinkovetskaia, I. S. (2020). Peculiarities of the English Legal Text Discourse: The Issues of Interpretation and Translatability. Journal of History Culture and Art Research, 9 (2), 318-328. http://doi.org/10.7596/taksad.v9i2.2689

Deleuze, J. (2004). Cinema. Moscow: Ad Marginem.

Dudley, A. (1984).Concepts in film theory. Oxford: Oxford University Press.

Eco, U. (2013). Inventing the Enemy. New York: Penguin Random House.

Foucault, M. (1996). What is an author? The will to truth: Beyond knowledge, power and sexuality. Works of different years. http://www.lib.ru/COPYRIGHT/fuko.txt

Gorodnycha, L. V., \& Olkhovyk, M. V. (2018). Articles editing as means of developing professional competence while teaching English for academic writing. Visnyk of Kyiv National Linguistic University, Series "Pedagogy and Psychology", 28, 61-69. http://nbuv.gov.ua/UJRN/Vknlu_Ptp_2018_28_10 
Helman, A. (1998).Creative betrayal: Film adaptations of literature [Twórcza zdrada: Filmowe adaptacje literatury]. Poznań: ArsNowa.

Hobsbawm, E., \& Ranger, T. (Eds.). (2010). The invention of tradition. Kyiv: Nika-Centre.

Hwan, K. S. (2015). Photogénie as “the Other" of the semiotics of cinema: On Yuri Lotman's concept of "the mythological". Semiotica, 2015 (207), 395-409. https://doi.org/10.1515/sem-2015-0050

Ivanova, N. (2011). The genesis of the film story in the works of Alexander Dovzhenko. World of Social Communications, 2, 170-174. http://194.44.152.155/elib/local/r69.pdf

Khrais, S. M. (2017). Literary Translation and Cultural Challenges: Jhumpa Lahiri's The Namesake. International Journal of Comparative Literature \& Translation Studies, 5(1), 80-86. http://doi.org/10.7575/aiac.ijclts.v.5n.1p.80

Koletnik, M. (2020). Teaching future translators' language through translation, does it help their translating? Current Trends in Translation Teaching and Learning, E (7), 314356.

http://www.cttl.org/uploads/5/2/4/3/5243866/cttl_e_2020_10_melita_koletnik.pdf

Lotman, Y. (1973). Semiotics of Cinema and problems of film aesthetics. Tallinn: Eesti Raamat.

Lotman, Yu. M. (1992). Text as a semiotic problem: Articles on semiotics and topology of culture. Vol. 1. Tallinn: Alexandra.

Mazower, M. (1 October 2012). Eric Hobsbawm: the history man. The Guardian. https://www.theguardian.com/books/2012/oct/01/eric-hobsbawm-history-man

McCaw, D. (2015). Bakhtin and Theatre: Dialogues with Stanislavsky, Meyerhold and Grotowski [Bakhtin e o teatro: diálogos com Stanislavsky, Meyerhold and Grotowski]. Abingdon: Routledge.

Monticelli, D. (2019). Borders and translation: Revisiting Juri Lotman's semiosphere. Semiotica, 2019(230), 389-406. https://doi.org/10.1515/sem-2017-0125

Moser, B. (2019). Sontag: Her Life and Work. New York: Ecco.

Perdikaki, K. (2017). Film adaptation as translation: an analysis of adaptation shifts in Silver $\begin{array}{llll}\text { Linings } & \text { Playbook. } & \text { Anafora, } & 4\end{array}$ (2), 249-265. https://www.academia.edu/35747144/Film_adaptation_as_translation_An_analysis_ of_adaptation_shifts_in_Silver_Linings_Playbook_Anafora_4_2_249_265

Perdikaki, K. (2018). Film adaptation as the interface between creative translation and cultural transformation: The case of Baz Luhrmann's The Great Gatsby. University of Surrey. The Journal of Specialised Translation, 29, 169-187. 
https://openresearch.surrey.ac.uk/esploro/outputs/journalArticle/Film-adaptation-asthe-interface-between/99514346102346

Reisenauer, A. (2015). Film, Literature, and Translation: The Reception of Spain in the United States. https://docplayer.net/30540609-Film-literature-and-translation.html

Sontag, S. (1964) Against Interpretation. https://bogcollectie.com/wpcontent/uploads/2021/05/Susan-Sontag.-Against-Interpretation.pdf

Valdeon, R. A. (2018). Topics and concepts in literary translation. Perspectives, 26(4), 459462. http://doi.org/10.1080/0907676X.2018.1465695

Viana da Silva, C. A. (2013). Modern narratives and film adaptation as translation Acta Scientiarum. Language and Culture Maringá, 35 (3), 269-274. https://www.redalyc.org/pdf/3074/307428857008.pdf

Wang, L., \& Wang, X. (2020). How to evaluate literary translations in the classroom context: through error analysis or scale-based method? Current Trends in Translation Teaching and Learning, $\quad$ E 276-313. http://www.cttl.org/uploads/5/2/4/3/5243866/cttl_e_2020_9_lyu_wang_and_xianglin g_wang.pdf

Zhuravel, T. (2018). Film translation as a type of audiovisual translation and it's development in Ukraine and worldwide. Research Journal of Drohobych Ivan Franko State Pedagogical University. Series "Philology (Linguistics)”, 10, 35-38. http://ddpufilolvisnyk.com.ua/uploads/arkhiv-nomerov/2018/NV_2018_10/11.pdf

Zubryts'ka, M. (2007).The reader as a theoretical category in the culturological discourse of the 20th century. Visnyk of Lviv National University: Issue Journalism, 31, 166-173. http://prima.franko.lviv.ua/faculty/jur/publications/visnyk31/Visnyk\%2031_P3_07_ Zubrycka.pdf 